Eduvest - Journal of Universal Studies

Volume 1 Number 11, November 2021

p- ISSN 2775-3735 e-ISSN 2775-3727

\title{
THE EFFECT OF PRINCIPAL SUPERVISION ON TEACHER PERFORMANCE IMPROVEMENT
}

Amirul Hidayat

Ahmad Dahlan University, Indonesia

E-mail: amirulhidayat97@gmail.com

\begin{tabular}{|c|c|}
\hline ARTICLE INFO & ABSTRACT \\
\hline $\begin{array}{l}\text { Received: } \\
\text { October, 26 } \\
2021 \\
\text { Revised: } \\
\text { November, } 16^{\text {th }} \\
2021 \\
\text { Approved: } \\
\text { November, } 18^{\text {th }} \\
2021\end{array}$ & $\begin{array}{l}\text { The goals to be achieved from a principal's supervision are } \\
\text { goals that are in accordance with predetermined } \\
\text { standards. Therefore, to ensure the quality of teaching } \\
\text { and learning services or good teacher performance, the } \\
\text { supervision of the principal is important in providing } \\
\text { guidance, guidance and supervision to teachers. This } \\
\text { supervision and improvement is something that must be } \\
\text { highlighted to become a benchmark for improving the } \\
\text { teaching and learning process that will result in good } \\
\text { quality education. The research used quantitative method } \\
\text { research was carried out for } 3 \text { months starting from } \\
\text { September to November } 2019 \text {. The place that became the } \\
\text { research center was at SDS IT Al Fajar Sungai Pakning. The } \\
\text { subject in this study was the principal while the object in } \\
\text { the study was the teacher at SDS IT Al Fajar. The } \\
\text { population in this study were principals and teachers. The } \\
\text { samples taken by the researchers were SDS IT teachers, Al } \\
\text { Fajar Sungai Pakning, totaling } 35 \text { people. After the } \\
\text { authors conducted data management through } \\
\text { questionnaires and analyzed the data, it can be concluded } \\
\text { that the supervision of the principal at Sds It Al Fajar } \\
\text { Sungai Pakning was categorized as "good" with a } \\
\text { percentage value of "100\%. }\end{array}$ \\
\hline KEYWORDS & Principal Supervision, Teacher Performance, Improvement \\
\hline c) (1) & $\begin{array}{l}\text { This work is licensed under a Creative C } \\
\text { Attribution-ShareAlike } 4.0 \text { International }\end{array}$ \\
\hline
\end{tabular}

Amirul Hidayat. (2021). The Effect of Principal Supervision on Teacher

Performance Improvement. Journal Eduvest. 1(11): 1225-1239

How to cite:

E-ISSN:

2775-3727

Published by: https://greenpublisher.id/ 


\section{INTRODUCTION}

Observing the development of an increasingly complex world of education, several strategies are needed that lead to an educational process that is able to answer the demands of the times. The existence of the principal in an educational institution is one of the keys and is required to be able to condition a professional work climate (Bryk \& Schneider, 2003), (Fullan, 2014).

The success of a school in improving the quality of education in schools cannot be separated from the leadership of a school principal. In the hands of the leader, program planning activities, organizing, implementing, monitoring, evaluating and so on. Can run well (Bonnario, Madiistriyatno, \& Zulfikar, 2021).

School leadership is an activity to direct, influence and control the entire potential of the school carried out by a principal in a systematic and programmed manner in order to achieve organizational goals (Bush \& Glover, 2014).

In order to improve the quality and performance of teachers at a level of education, it is very necessary to carry out supervision (Madiistriyatno \& Sofianto, 2021). The term supervision is different from inspection. Inspection aims to check to what extent a plan has been implemented, whether the conditions and activities are in accordance with the provisions that have been outlined, while supervision aims to find or identify the capabilities and inability of personnel to provide assistance and services to these personnel in order to improve their abilities or expertise (Harries, 2020).

According to the Regulation of the Minister for Empowerment of State Officials and Reform No. 16 of 2009 concerning the functional positions of teachers and the number of credits, article 5 paragraph 1 explains that the main task of teachers is to educate, teach, guide, direct, train, assess, and evaluate students in early childhood education. early formal education, basic education, and secondary education as well as additional tasks relevant to the function of the school/madrasah.

In an effort to improve the quality of educational resources, teachers are a component of human resources that must be fostered and developed continuously (Hénard \& Roseveare, 2012). The task of the teacher is related to efforts to educate the nation's life in all its aspects, both spiritual, emotional, intellectual, and other aspects (Zakuan et al., 2012). The potential of teachers must continue to develop in order to carry out their potential functions (Schleicher, 2012).

One of the efforts to improve teacher performance in the learning process is the role of the principal as a supervisor in supervising teacher performance in teaching, because the success or failure of the learning process in schools is largely determined by the performance of a teacher's teaching skills (Azwardi, 2020).

The principal is the center of leader who regulates and manages activities to be directed, focused and experienced a significant improvement (Oyewole \& Alonge, 2013). Therefore, principals play an important role in improving teacher performance and developing themselves in transferring knowledge to students (Wanzare, 2012). The principal must have advantages that are prioritized to better supervise his subordinates so that they remain qualified in carrying out the obligations of a teacher and education staff. This is because the principal's job is to oversee the activities that have been programmed to be directed, focused and successful.

Principals play an important role in creating personal and teachers who are dedicated to the responsibility of educating their students (DiPaola, Tschannen-Moran, \& Walther-Thomas, 2004). With a very basic reason that teachers have a role in determining the quality of teaching carried out, therefore teachers think and plan carefully in increasing student learning opportunities by improving the quality of teachers in 
managing the teaching and learning process (Bastable, 2017).

The principal is a supporter and also an intermediary who has a role as a supervisor or supervisor because the principal is a functional staff who is given more duties to lead a school in which the teaching and learning process is held or a place where interactions occur between teachers who give lessons and students who receive lessons. Lesson (Stronge \& Xu, 2021).

The goals to be achieved from a principal's supervision are goals that are in accordance with predetermined standards. Therefore, to ensure the quality of teaching and learning services or good teacher performance, the supervision of the principal is important in providing guidance, guidance and supervision to teachers. This supervision and improvement is something that must be highlighted to become a benchmark for improving the teaching and learning process that will result in good quality education.

Therefore, as a supervisor, the principal is expected to be able to act as a consultant, as a facilitator who understands the needs of the teacher and is also able to provide alternative solutions. While acting as a supervisor, the principal is expected to guide and motivate teachers to be more creative and innovative.

\section{RESEARCH METHOD}

The research used quantitative method, this research was carried out for 3 months starting from September to November 2019. The place that became the research center was at SDS IT Al Fajar Sungai Pakning. The subject in this study was the principal while the object in the study was the teacher at SDS IT Al Fajar. The population in this study were principals and teachers. The samples taken by the researchers were SDS IT teachers, Al Fajar Sungai Pakning, totaling 35 people.

Researchers conducted interviews with school principals to find out how the principal supervised. Furthermore, researchers distributed questionnaires to SDS IT teachers at Al Fajar Sungai Pakning in order to obtain accurate information on how big the percentage of principal supervision and teacher performance is and how it affects teacher performance. Furthermore, the authors took several important documents and photos to add data in the study. After distributing the questionnaire and filling out the questionnaire by the teachers of SDs IT Al Fajar, the researchers processed the questionnaire using a quantitative descriptive formula to determine the percentage of principal supervision and teacher performance at SDs IT Al Fajar. The quantitative descriptive formula is as follows:

$$
\mathrm{P}=\frac{F}{N} \times 100 \%
$$

Information:

$\mathrm{P}=$ Percentage Number

$\mathrm{F}=$ Frequency being searched for percentage

$\mathrm{N}=$ Number of cases (Number of frequency/number of individuals)

Furthermore, to find out whether there is an effect of principal supervision on improving teacher performance at SDs It Al Fajar, the researchers processed questionnaire data using a simple linear regression formula. The formula used in this research is simple linear regression.

$\mathrm{Y}=\mathrm{A}+\mathrm{BX}+\mathrm{e}$

$\mathrm{Y}=$ Dependent variable or response

$\mathrm{A}=$ is the intercept or constant

$\mathrm{B}=$ is the regression coefficient or slope

$\mathrm{E}=$ is residual or error 


\section{Data Analysis}

\section{RESULT AND DISCUSSION}

a. Questionnaire validity test

Validity test is a test used to show the extent to which the measuring instrument used in a measure is what is being measured. A questionnaire is said to be valid if the questions on the questionnaire are able to reveal something that will be measured by the questionnaire.

The researcher has 15 statements that will be tested on 13 teachers. The results of the validity of the statement items are as follows:

Table 1 Validity Test Results of Principal Supervision Variables and Teacher

Performance

\begin{tabular}{llll}
\hline & \multicolumn{3}{c}{ Case Processing Summary } \\
\hline \multirow{3}{*}{ Cases } & $\mathrm{N}$ & $\%$ \\
\hline & Valid $^{\mathrm{a}}$ & 13 & 100,0 \\
\cline { 2 - 4 } & Excluded $^{\mathrm{a}}$ & 0 & 0 \\
\cline { 2 - 4 } & Total $^{*}$ & 13 & 100,0 \\
\hline
\end{tabular}

a. Listwise deletion based on all variables in the procedure.

Source: Results of the management of SPSS 25.0 (2019)

Based on the table above, the questionnaire is said to be valid because it is greater than 0.5140 .

Table 2 Reliability Test Results

\begin{tabular}{llll}
\hline & \multicolumn{3}{c}{ Case Processing Summary } \\
\hline \multirow{3}{*}{ Cases } & \multicolumn{1}{c}{$\mathrm{N}$} & $\%$ \\
\cline { 2 - 4 } & Valid & 13 & 100,0 \\
\cline { 2 - 4 } & Excluded $^{\mathrm{a}}$ & 0 & 0 \\
\cline { 2 - 4 } & Total & 13 & 100,0 \\
\hline
\end{tabular}

a. Listwise deletion based on all variables in the procedure.

\begin{tabular}{lc}
\hline & Reliability Statistics \\
\hline Cronbach's Alpha & N of Items \\
\hline 790 & 16 \\
\hline
\end{tabular}

Item-Total Statistics

Scale Mean if ItemScale Variance ifCorrected Item-Cronbach's Alpha Deleted Item Deleted Total Correlation if Item Deleted

\begin{tabular}{lllll}
\hline item_1 & 86,54 & 235,103 &, 710 &, 773 \\
\hline item_2 & 86,54 & 229,269 &, 773 &, 767 \\
\hline item_3 & 86,23 & 241,359 &, 423 &, 782 \\
\hline item_4 & 86,38 & 234,090 &, 635 &, 773 \\
\hline item_5 & 86,54 & 235,103 &, 710 &, 773 \\
\hline item_6 & 86,54 & 235,103 &, 710 &, 773 \\
\hline item_7 & 86,54 & 229,269 &, 773 &, 767 \\
\hline item_8 & 86,38 & 234,090 &, 635 &, 773 \\
\hline item_9 & 86,31 & 241,564 &, 400 &, 782 \\
\hline item_10 & 86,23 & 241,359 &, 423 &, 782
\end{tabular}




\begin{tabular}{lllll}
\hline item_11 & 86,54 & 235,103 &, 710 &, 773 \\
\hline item_12 & 86,23 & 241,359 &, 423 &, 782 \\
\hline item_13 & 86,38 & 234,090 &, 635 &, 773 \\
\hline item_14 & 86,23 & 241,359 &, 423 &, 782 \\
\hline item_15 & 86,54 & 235,103 &, 710 &, 773 \\
\hline Skor_total 41,15 & 90,141 &, 815 &, 909 \\
\hline
\end{tabular}

a. If cronbach alpha $>\mathrm{r}$ table $=$ consistent/reliable

b. If cronbach alpha $<\mathrm{r}$ table $=$ inconsistent $/$ reliable

Based on the reliability test above, the alpha value is greater than $r$ table so it can be said that the questionnaire data is reliable.

As for the aspects that are in the questionnaire according to the research problem, namely 7 aspects that are in accordance with the indicators on the operational concept, using two alternative answers "always, often, rarely and never which are displayed in tabular form, for more details can be seen on the presentation sheet. following data:

A. Description of the frequency and percentage of statement items in the Principal Supervision Questionnaire at Sds It Al Fajar Sungai Pakning Sejangat Village, Bukit Batu District, Bengkalis Regency

The Principal Supervision variable questionnaire consists of 6 indicators represented by 7 statements. To see the frequency and percentage of each item statement can be seen in the table below:

Table 3. The principal provides assistance to the teacher so that the initiative is focused on the teacher's opinion

\begin{tabular}{llll}
\hline Option & Alternative Answer & F & P (\%) \\
\hline A & Always & -4 & $11,43 \%$ \\
\hline B & Often & 23 & $65,71 \%$ \\
\hline C & Rarely & 8 & $22,86 \%$ \\
\hline D & Never & - & - \\
\hline Total & & 35 & $100 \%$ \\
\hline
\end{tabular}

From the table above, it can be seen that the principal provides assistance to teachers so that the initiative is focused on the teacher, namely 4 respondents or $11.43 \%$ answered always, 23 respondents or $65.71 \%$ answered often, 8 respondents or $22.86 \%$ answered rarely. , and none of the respondents answered never. From this questionnaire statement, it can be seen that the total number of respondents or the percentage is more in the frequent answers, namely $65.71 \%$.

Table 4. The principal accepts the teacher's proposal and conducts a joint study to make an agreement to be implemented.

\begin{tabular}{llll}
\hline Option & Alternative Answer & F & P (\%) \\
\hline A & Always & 6 & $17,14 \%$ \\
\hline B & Often & 19 & $54,28 \%$ \\
\hline C & Rarely & 10 & $28,57 \%$ \\
\hline D & Never & & \\
\hline Total & & 35 & $100 \%$ \\
\hline
\end{tabular}

From the table above, the principal can accept the teacher's proposal and conduct a joint study to make an agreement that will be carried out, namely 6 respondents or 


\section{Amirul Hidayat}

$17.14 \%$ answered always, 19 respondents or $54.28 \%$ answered often, 10 respondents or $28.57 \%$ rarely answered, and none of the respondents answered never. From this questionnaire statement, it can be seen that the total number of respondents or percentage is more in the always answer, namely $54.28 \%$.

Table 5. The principal provides the instruments and methods of observation that will be developed with the teacher.

\begin{tabular}{llll}
\hline Option & Alternative Answer & F & P (\%) \\
\hline A & Always & 4 & $11,43 \%$ \\
\hline B & Often & 17 & $48,57 \%$ \\
\hline C & Rarely & 14 & $40,00 \%$ \\
\hline D & Never & & \\
\hline Total & & 35 & $100 \%$ \\
\hline
\end{tabular}

From the table above, it can be seen that the principal gave the instruments and observation methods to be developed with the teacher, namely 4 respondents or $11.43 \%$ answered always, 17 respondents or $48.57 \%$ answered often, 14 respondents or $40.00 \%$ answered rarely., and none of the respondents answered never. From this questionnaire statement, it can be seen that the total number of respondents or the percentage is more in the frequent answers, namely $48.57 \%$.

Table 6 The principal conducts observation and feedback activities.

\begin{tabular}{llll}
\hline Option & Alternative Answer & F & P (\%) \\
\hline A & Always & 8 & $22,86 \%$ \\
\hline B & Often & 17 & $48,57 \%$ \\
\hline C & Rarely & 13 & $37,14 \%$ \\
\hline D & Never & - & - \\
\hline Total & & 35 & $100 \%$ \\
\hline
\end{tabular}

From the table above, it can be seen that the principal who carried out observation activities and carried out feedback activities was 8 respondents or $22.86 \%$ answered always, 17 respondents or $48.57 \%$ answered often, 13 respondents or $37.14 \%$ answered rarely, and no. There are respondents who answered never. From this questionnaire statement, it can be seen that the total number of respondents or the percentage is more in the frequent answers, namely $48.57 \%$.

Table 7. The principal discusses the results of the analysis and observational data by prioritizing the teacher's interpretation

\begin{tabular}{|c|c|c|c|}
\hline Option & Alternative Answer & $\mathrm{F}$ & $\mathrm{P}(\%)$ \\
\hline $\mathrm{A}$ & Always & 8 & $22,86 \%$ \\
\hline B & Often & 26 & $74,28 \%$ \\
\hline $\mathrm{C}$ & Rarely & 1 & $2,86 \%$ \\
\hline $\mathrm{D}$ & Never & & \\
\hline \multicolumn{2}{|c|}{ Total } & 35 & $100 \%$ \\
\hline
\end{tabular}


From the table above, it can be seen that the principal discussed the results of the analysis and observational data by prioritizing the teacher's interpretation, namely 8 respondents or $22.86 \%$ answered always, 26 respondents or $74.28 \%$ answered often, 1 respondent or $2.86 \%$ answered rarely., and none of the respondents answered never. From this questionnaire statement, it can be seen that the total number of respondents or the percentage is more in the always answer, which is $74.28 \%$.

Table 8 Principals supervise face-to-face and in an open atmosphere

\begin{tabular}{llll}
\hline Option & Alternative Answer & F & P (\%) \\
\hline A & Always & 12 & $34,28 \%$ \\
\hline B & Often & 15 & $42,86 \%$ \\
\hline C & Rarely & 8 & $22,86 \%$ \\
D & Never & & \\
Total & & 35 & $100 \%$ \\
\hline
\end{tabular}

From the table above, it can be seen that the principal supervises face-to-face and in an open atmosphere, 12 respondents or $34.28 \%$ answered always, 15 respondents or $42.86 \%$ answered often, 8 respondents or $22.86 \%$ answered rarely. , and none of the respondents answered never. From this questionnaire statement, it can be seen that the total respondents or percentages are more frequently answered, namely $42.86 \%$.

Table 9. The principal listens more to and answers the teacher's questions than gives direction

\begin{tabular}{llll}
\hline Option & Alternative Answer & F & P (\%) \\
\hline A & Always & 6 & $17,14 \%$ \\
\hline B & Often & 19 & $54,28 \%$ \\
\hline C & Rarely & 10 & $28,57 \%$ \\
\hline D & Never & & \\
\hline Total & & 35 & $100 \%$ \\
\hline
\end{tabular}

From the table above, it can be seen that the principal listens more and answers teacher questions rather than giving directions, namely 6 respondents or $17.14 \%$ answered always, 19 respondents or $54.28 \%$ answered often, 10 respondents or $28.57 \%$ answered rarely once, and none of the respondents answered never. From this questionnaire statement, it can be seen that the total respondents or percentages are more frequently answered, namely $54.28 \%$

Table 10 Principals carry out three stages, namely, initial meetings, observations, and feedback meetings in supervision

\begin{tabular}{llll}
\hline Option & Alternative Answer & F & P (\%) \\
\hline A & Always & 16 & $45,71 \%$ \\
\hline B & Often & 2 & $5,71 \%$ \\
\hline C & Rarely & 17 & $48,57 \%$ \\
\hline D & Never & & \\
Total & & 35 & $100 \%$ \\
\hline
\end{tabular}

From the table above, it can be seen that the principal carried out three stages, namely, initial meetings, observations, and feedback meetings in supervision, namely 16 respondents or $45.71 \%$ answered always, 2 respondents or $5.71 \%$ answered often, 17 


\section{Amirul Hidayat}

respondents or 48, 57\% answered rarely, and none of the respondents answered never. From this questionnaire statement, it can be seen that the total number of respondents or the percentage is more in the frequent answers, namely $48.57 \%$.

Table 11. Principals provide reinforcement for positive behavior change as a result of coaching.

\begin{tabular}{llll}
\hline Option & Alternative Answer & F & P (\%) \\
\hline A & Always & 3 & $8,57 \%$ \\
\hline B & Often & 25 & $71,43 \%$ \\
C & Rarely & 7 & $20,00 \%$ \\
\hline D & Never & & \\
\hline Total & & 35 & $100 \%$ \\
\hline
\end{tabular}

From the table above, it can be seen that the principal gave reinforcement to positive behavior changes as a result of coaching, namely 3 respondents or $8.57 \%$ answered always, 25 respondents or $71.43 \%$ answered often, 7 respondents or $20.00 \%$ answered rarely, and none of the respondents answered never. From the statement of this questionnaire, it can be seen that the total respondents or percentages are more frequently answered, namely $71.43 \%$.

Table 12 The principal conducts a follow-up review of the supervision that has been carried out

\begin{tabular}{llll}
\hline Option & Alternative Answer & F & P (\%) \\
\hline A & Always & 10 & $28,57 \%$ \\
\hline B & Often & 19 & $54,28 \%$ \\
C & Rarely & 6 & $17,14 \%$ \\
\hline D & Never & & \\
\hline Total & & 35 & $100 \%$ \\
\hline
\end{tabular}

From the table above, it can be seen that the principal who carried out a continuation review of the supervision that had been carried out was 10 respondents or $28.57 \%$ answered always, 19 respondents or $54.28 \%$ answered often, 6 respondents or $17.14 \%$ answered rarely, and no There are respondents who answered never. From the statement of this questionnaire, it can be seen that the total respondents or percentages are more frequently answered, namely $71.43 \%$.

Table 13 Recapitulation results for the percentage of the Principal Supervision Questionnaire at Al Fajar Elementary School:

$$
\text { Alternative Answer }
$$

Respondent

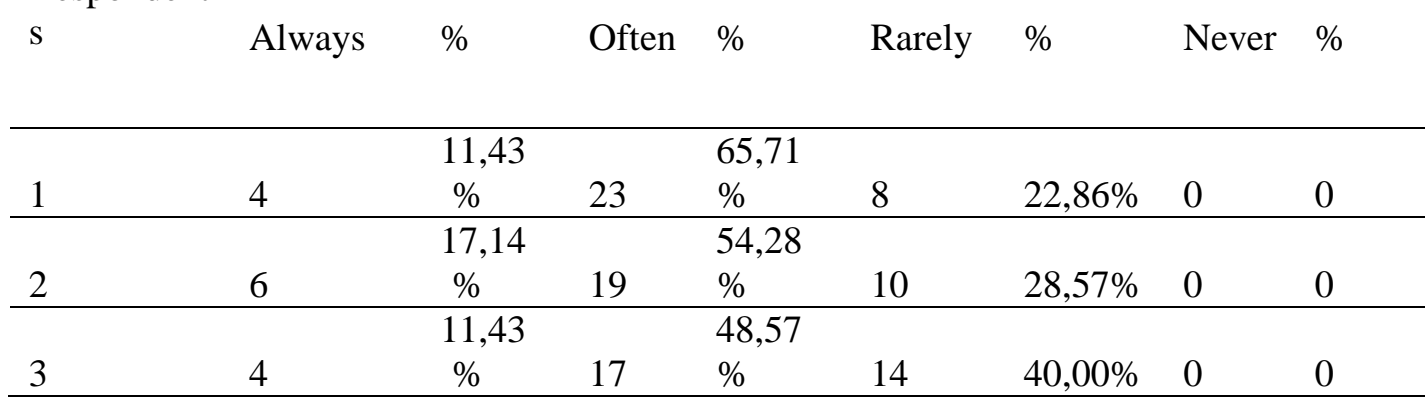




\begin{tabular}{|c|c|c|c|c|c|c|c|c|}
\hline \multirow[b]{2}{*}{4} & \multicolumn{3}{|c|}{22,86} & \multicolumn{2}{|l|}{48,57} & \multirow[b]{2}{*}{$37,14 \%$} & \multirow[b]{2}{*}{0} & \multirow[b]{2}{*}{0} \\
\hline & 8 & $\%$ & 17 & $\%$ & 13 & & & \\
\hline & & 22,86 & & 74,28 & & & & \\
\hline 5 & 8 & $\%$ & 26 & $\%$ & 1 & $2,86 \%$ & 0 & 0 \\
\hline & & 34,28 & & 42,86 & & & & \\
\hline 6 & 12 & $\%$ & 15 & $\%$ & 8 & $22,86 \%$ & 0 & 0 \\
\hline 7 & 6 & 17,14 & 19 & $\begin{array}{l}54,28 \\
\%\end{array}$ & 10 & $28,57 \%$ & 0 & 0 \\
\hline & & 45,71 & & & & & & \\
\hline 8 & 16 & $\%$ & 2 & $5,71 \%$ & 17 & $48,57 \%$ & & \\
\hline & & & & 71,43 & & & & \\
\hline 9 & 3 & $8,57 \%$ & 25 & $\%$ & 7 & $20,00 \%$ & & \\
\hline & & 28,57 & & 54,28 & & & & \\
\hline 10 & 10 & $\%$ & 19 & $\%$ & 6 & $17,14 \%$ & & \\
\hline Total & 77 & & 182 & & 94 & & 0 & \\
\hline
\end{tabular}

From the recapitulation of the Education Supervision questionnaire at SD IT Al Fajar, it can be seen that the percentage figures are as follows:

1. Alternative Answer Option $\mathrm{A}=77: 10=7,7: 35 \times 100=22 \%$

2. Alternative Answer Option $\mathrm{B}=182: 10=18.2: 35 \times 100=52 \%$

3. Alternative Answer Option C $=94: 10=9,4: 35 \times 100=26 \%$

4. Alternative Answer Option $\mathrm{D}=$ none

So, the percentage of the questionnaire recapitulation of educational supervision at SD It Al Fajar above can be seen that the highest score is in alternative answer B, which is $52 \%$, the second is answer $\mathrm{C}$, which is $26 \%$, and the lowest is in alternative $\mathrm{A}$, which is $22 \%$.

Based on the above recapitulation regarding educational supervision at SDS IT Al Fajar, it can be given a score and percentage as follows:
A : $77 \times 4=308$
B : $182 \times 4=728$
C : $94 \times 4=376$
D : -
Total:

- $\mathrm{N}=308+728+376=1412 \times 4=5.648$

- $\mathrm{P}=\frac{F}{N} \times 100 \%$

$\mathrm{P}=\frac{5648}{5648} \times 100 \%$

$\mathrm{P}=\frac{564800}{5648}$

$\mathrm{P}=100 \%$

Based on the results of the instrument table percentage of the principal supervision questionnaire distributed to 35 respondents, it can be concluded that the principal's supervision is categorized as "good" with the total percentage of "100\%".

a. Description of the frequency and percentage of statement items in the teacher performance questionnaire at Elementary School It Al Fajar Sungai Pakning, Sejangat Village, Bukit Batu District, Bengkalis Regency.

The teacher performance variable questionnaire consists of 5 indicators represented by 5 statements. To see the frequency and percentage of each item statement can be seen in the table below: 


\section{Amirul Hidayat}

Table 14. Teachers are able and master the teaching materials that will be given to students.

\begin{tabular}{llll}
\hline Option & Alternative Answer & F & P (\%) \\
\hline A & Always & 15 & $42,85 \%$ \\
\hline B & Often & 12 & $34,28 \%$ \\
\hline C & Rarely & 8 & $22,86 \%$ \\
\hline D & Never & & \\
\hline Total & & 35 & $100 \%$ \\
\hline
\end{tabular}

From the table above, it can be seen that teachers are able and master the teaching materials that will be given to students, namely 15 respondents or $42.85 \%$ answered always, 12 respondents or $34.28 \%$ answered often, 8 respondents or $22.86 \%$ answered rarely. , and none of the respondents answered never. From this questionnaire statement, it can be seen that the total number of respondents or the percentage is more in the always answer, namely $42.85 \%$.

Table 15 The teacher prepares the planning of the teaching and learning process in the classroom.

\begin{tabular}{llll}
\hline Option & Alternative Answer & F & P (\%) \\
\hline A & Always & 17 & $48,57 \%$ \\
\hline B & Often & 11 & $31,43 \%$ \\
C & Rarely & 7 & $20,00 \%$ \\
\hline D & Never & & \\
\hline & & 35 & $100 \%$ \\
\hline
\end{tabular}

From the table above, it can be seen that the teacher preparing the planning for the teaching and learning process in the classroom is 17 respondents or $48.57 \%$ answered always, 11 respondents or $31.43 \%$ answered often, 7 respondents or $20.00 \%$ answered rarely, and no respondents answer never. From this questionnaire statement, it can be seen that the total number of respondents or percentage is more in the always answer, namely $48.57 \%$.

Table 16. Teachers have the ability to implement and manage the teaching and learning process

\begin{tabular}{|c|c|c|c|}
\hline Option & Alternative Answer & $\mathrm{F}$ & $\mathrm{P}(\%)$ \\
\hline A & Always & 10 & $28,57 \%$ \\
\hline B & Often & 19 & $54,28 \%$ \\
\hline $\mathrm{C}$ & Rarely & 5 & $14,28 \%$ \\
\hline $\mathrm{D}$ & Never & & \\
\hline Total & & 35 & $100 \%$ \\
\hline
\end{tabular}

From the table above, it can be seen that teachers have the ability to carry out and manage the teaching and learning process, namely 10 respondents or $28.57 \%$ answered always, 19 respondents or $54.28 \%$ answered often, 5 respondents or $14.28 \%$ answered rarely, and no. There are respondents who answered never. From this questionnaire statement, it can be seen that the total number of respondents or the percentage is more in 
the always answer, which is $54.28 \%$.

Table 17 The teacher has the ability to evaluate and provide an assessment according to the material that has been taught.

\begin{tabular}{|c|c|c|c|}
\hline Option & Alternative Answer & $\mathrm{F}$ & $\mathrm{P}(\%)$ \\
\hline A & Always & 13 & $37,14 \%$ \\
\hline B & Often & 17 & $48,57 \%$ \\
\hline $\mathrm{C}$ & Rarely & 5 & $14,28 \%$ \\
\hline D & Never & & \\
\hline \multicolumn{2}{|c|}{ Total } & 35 & $100 \%$ \\
\hline
\end{tabular}

From the table above, it can be seen that the teacher has the ability to evaluate and provide an assessment according to the material that has been taught, namely 13 respondents or $37.14 \%$ answered always, 17 respondents or $48.57 \%$ answered often, 5 respondents or $14.28 \%$ answered rarely once, and none of the respondents answered never. From this questionnaire statement, it can be seen that the total number of respondents or percentage is more in the always answer, namely $48.57 \%$.

Table 18 Teachers have the ability to carry out tutoring (improvement and enrichment) after the teaching process

\begin{tabular}{llll}
\hline Option & Alternative Answer & F & P (\%) \\
\hline A & Always & 7 & $20,00 \%$ \\
\hline B & Often & 13 & $37,14 \%$ \\
\hline C & Rarely & 15 & $42,86 \%$ \\
\hline D & Never & & \\
\hline \multicolumn{1}{r}{ Total } & & 35 & $100 \%$ \\
\hline
\end{tabular}

From the table above, it can be seen that the teacher has the ability to carry out tutoring (improvement and enrichment) after the teaching process is 7 respondents or $20.00 \%$ answered always, 13 respondents or $37.14 \%$ answered often, 15 respondents or $42.86 \%$ answered rarely once, and none of the respondents answered never. From this questionnaire statement, it can be seen that the total number of respondents or the percentage is more in the always answer, which is $42.86 \%$.

Table 19 Recapitulation results for the percentage of the Teacher Performance Questionnaire at Al Fajar Elementary School:

\begin{tabular}{|c|c|c|c|c|c|c|c|c|}
\hline \multirow[b]{2}{*}{ Respondents } & \multicolumn{4}{|c|}{ Alternative Answers } & \multirow[b]{2}{*}{ Rarely } & \multirow[b]{2}{*}{$\%$} & \multirow[b]{2}{*}{ Never } & \multirow[b]{2}{*}{$\%$} \\
\hline & Always & $\%$ & Often & $\%$ & & & & \\
\hline & & 42,86 & & & & & & \\
\hline 1 & 15 & $\%$ & 12 & $34,28 \%$ & 8 & $22,86 \%$ & 0 & 0 \\
\hline 2 & 17 & $\begin{array}{l}48,57 \\
\%\end{array}$ & 11 & $31,43 \%$ & 7 & $20,00 \%$ & 0 & 0 \\
\hline 3 & 11 & $\begin{array}{l}31,43 \\
\%\end{array}$ & 19 & $54,28 \%$ & 5 & $14,28 \%$ & 0 & 0 \\
\hline 4 & 13 & $\begin{array}{l}37,14 \\
\%\end{array}$ & 17 & $48,57 \%$ & 5 & $14,28 \%$ & 0 & 0 \\
\hline 5 & 7 & $\begin{array}{l}20,00 \\
\%\end{array}$ & 13 & $37,14 \%$ & 15 & $42,86 \%$ & 0 & 0 \\
\hline
\end{tabular}




\section{Amirul Hidayat}

\begin{tabular}{lllll}
\hline Quantity & 63 & 72 & 40 & 0 \\
\hline
\end{tabular}

From the recapitulation of the Education Supervision questionnaire at SD IT Al Fajar, it can be seen that the percentage figures are as follows:

1. Alternative answer option $\mathrm{A}=63: 5=12,6: 35 \times 100=36 \%$

2. Alternative answer option $B=72: 5=14,4: 35 \times 100=41 \%$

3. Alternative answer option $\mathrm{C}=40: 5=8: 35 \times 100=23 \%$

4. Alternative answer option $\mathrm{D}=$ none

So, the percentage of the questionnaire recapitulation of educational supervision at SD It Al Fajar above can be seen that the highest score is in alternative answer B, which is $41 \%$, the second is answer $\mathrm{A}$, which is $36 \%$, and the lowest is alternative $\mathrm{C}$, which is $23 \%$.

Based on the above recapitulation regarding the supervision of education at SD It Al Fajar can be given a score and percentage as follows:
A : $63 \times 4=252$
B : $72 \times 4=288$
C : $40 \times 4=160$
$\mathrm{D}:-$
Total number:

- $\mathrm{N}=252+288+160=700 \times 4=2800$

- $\mathrm{P}=\frac{F}{N} \times 100 \%$

$\mathrm{P}=\frac{2800}{2800} \times 100 \%$

$\mathrm{P}=\frac{280000}{2800}$

$\mathrm{P}=100 \%$

Based on the results of the instrument table percentage of the Teacher Performance questionnaire distributed to 35 respondents, it can be concluded that the principal's supervision is categorized as "Good" with the total percentage of "100\%".

B. Analysis of data on the effect of principal supervision on improving teacher performance at SD It Al Fajar Sejangat, Bukit Batu sub-district.

To determine the effect of the independent variable (principal's supervision) on the dependent variable (teacher performance) at It Al Fajar Elementary School, Bukit Batu District, statistical analysis was carried out.

Before the researcher calculates how much influence the independent variable has on the dependent variable, the researcher carries out a data normality test. For normality testing in this study, researchers used statistical analysis. Normality test based on non-parametric Kolmogorov-Smiraow (K-S) test. If the value of KolmogorovSmiraow $\mathrm{Z}<\mathrm{Z}$ table asymp Sig (2 tailed) $>$ then the data is declared to be normally distributed. The following is table 4.24 for the Kolmogorov-Smiraow test.

1. The basis for making normality test decisions are:

2. If the value of asymp sig. 2 tailed above $5 \%$ or 0.05 then the data is considered normally distributed.

3. If the value of asymp sig 2 tailed is below $5 \%$ or 0.05 then the data is considered to be not normally distributed. 
Table 20 Kolmogorov-Smiraow Test Results

\begin{tabular}{|c|c|c|c|}
\hline \multicolumn{4}{|c|}{ One-Sample Kolmogorov-Smirnov Test } \\
\hline & & & Unstandardized Residual \\
\hline \multicolumn{2}{|l|}{$\mathrm{N}$} & & 35 \\
\hline \multirow{2}{*}{$\begin{array}{c}\text { Normal } \\
\text { Parameters }{ }^{\mathrm{a}, \mathrm{b}}\end{array}$} & & Mean & 0E-7 \\
\hline & & Std. Deviation & 1,99027875 \\
\hline \multirow{3}{*}{$\begin{array}{r}\text { Most } \\
\text { Differences }\end{array}$} & \multirow{3}{*}{ Extreme- } & Absolute &, 131 \\
\hline & & Positive &, 131 \\
\hline & & Negative &,- 093 \\
\hline \multicolumn{3}{|c|}{ Kolmogorov-Smirnov Z } & ,773 \\
\hline \multicolumn{3}{|c|}{ Asymp. Sig. (2-tailed) } & $\begin{array}{c}589 \\
\end{array}$ \\
\hline \multicolumn{4}{|c|}{ a. Test distribution is Normal. } \\
\hline \multicolumn{4}{|c|}{ b. Calculated from data. } \\
\hline
\end{tabular}

Based on the test table above, the Aymp Sig ( 2 tailed) value is greater than 0.05 . So according to the basis of decision making in the Kolmogorov-Smirnov normality test above, it can be concluded that the data are normally distributed. Thus, the assumptions or requirements for normality in the regression model have been met.

After passing the data normality test, the data is ready to be regressed to a simple linear. The results of simple linear regression can be seen in table 4.25 below:

Table 21 Simple Linear Regression Results

\begin{tabular}{|c|c|c|c|c|c|c|}
\hline \multicolumn{7}{|c|}{ Coefficients ${ }^{\mathrm{a}}$} \\
\hline \multirow[t]{2}{*}{ Model } & & \multicolumn{3}{|c|}{$\begin{array}{r}\text { Unstandardized Coefficients Standardized } \\
\text { Coefficients }\end{array}$} & $\mathrm{T}$ & Sig. \\
\hline & & $\overline{\mathrm{B}}$ & Std. Error & Beta & & \\
\hline & (Constant) & 27,384 & 14,309 & & 1,914 & 064 \\
\hline 1 & $\begin{array}{l}\text { Supervisi } \\
\text { Pendidikan }\end{array}$ & 081 & ,398 &, 035 & 203 & ,840 \\
\hline
\end{tabular}

a. Dependent Variable: Kinerja Guru

From table 4.25 above, it can be seen that constant (a) is 20.672, while the value of the principal's supervision (regression coefficient) is 0.004 , so the regression equation can be written as follows:

$\mathrm{a}=$ constant number of unstandardzied coefficient is 20,672 which means that if there is supervision of the principal $(\mathrm{X})$ then the consistent value of teacher performance (Y) is 20,672 .

$\mathrm{b}=$ regression coefficient of 0.004 which means that for every $1 \%$ addition to the level of supervision of the principal (X), the teacher's performance (Y) will increase by 0.004 .

Because the value of the regression coefficient is low, it can be said that the principal's supervision has no effect on teacher performance. So the regression equation is $\mathrm{Y}=20,672-0,004 \mathrm{X}$

Table 22 Value of Coefficient of Determination

\begin{tabular}{|c|c|c|c|c|}
\hline \multicolumn{3}{|c|}{ Model Summary } & & \\
\hline$\overline{\text { Model }}$ & $\mathrm{R}$ & R Square & $\begin{array}{l}\text { Adjusted } \\
\text { Square }\end{array}$ & RStd. Error of the Estimate \\
\hline 1 &, $035^{\mathrm{a}}$ & ,001 &,- 029 & 4,818 \\
\hline
\end{tabular}




\section{Amirul Hidayat}

1. The $\mathrm{R}$ value of 0.035 is equal to $6.0 \%$ which indicates that the supervision of the principal $(\mathrm{X})$ at It Al Fajar Elementary School has no relationship with Teacher Performance (Y) at It Al Fajar Elementary School, Sungai Pakning.

2. R Squared value of 0.001 . This value means that there is a significant influence between the supervision of the principal (X) of $10 \%$ on the performance of teachers (X) at SD It Al Fajar Sungai Pakning.

Based on the results of the recapitulation of percentage calculations and simple linear regression on the effect of principal supervision $(\mathrm{X})$ on teacher performance $(\mathrm{Y})$ are as follows:

1. The percentage value of the principal's supervision is "100\%" and is categorized as Good.

2. While the percentage of teacher performance at SD It Al Fajar is "100\%" and is categorized as Good.

The results of the linear regression test of the influence of the principal's supervision (X) on teacher performance (Y) at SD It Al Fajar Sungai Pakning the value is $10 \%$ and is declared to have an effect.

\section{CONCLUSION}

After the authors conducted data management through questionnaires and analyzed the data, it can be concluded that the supervision of the principal at Sds It Al Fajar Sungai Pakning was categorized as "good" with a percentage value of "100\%. The percentage results indicate that the principal carries out supervision well by carrying out supervisory tasks such as class visits, class observations, teacher meetings and carrying out evaluations to teachers after carrying out teaching and learning supervision. While the teacher's performance at SD It Al Fajar is categorized as "good" with a percentage value of "100\%", this can be seen by the teacher's role in discipline following the rules such as preparing teaching materials before teaching, providing materials according to teaching materials, and evaluating learning after finishing teaching and guiding students who have problems outside the classroom. The results of the linear regression test of the influence of the supervision of the principal $(\mathrm{X})$ on the performance of teachers $(\mathrm{Y})$ at SD It $\mathrm{Al}$ Fajar Sungai Pakning the value is $10 \%$ and is declared to have an effect seen from the results of the linear regression test.

\section{REFERENCES}

Azwardi, Azwardi. (2020). Efforts to improve teacher competency in developing learning materials through collaborative academic supervision. Indonesian Educational Administration and Leadership Journal, 2(1), 1-12.

Bastable, Susan B. (2017). Nurse as Educator: Principles of Teaching and Learning for Nursing Practice: Principles of Teaching and Learning for Nursing Practice. Jones $\&$ Bartlett Learning.

Bonnario, Moh, Madiistriyatno, Harries, \& Zulfikar, Azis. (2021). Human Resource Training and Planning for Work Productivity of Employees Ministry of Coordinating Ministry of Human Development and Culture. Eduvest-Journal Of Universal Studies, 1(9), 961-969.

Bryk, Anthony S., \& Schneider, Barbara. (2003). Trust in schools: A core resource for school reform. Educational Leadership, 60(6), 40-45.

Bush, Tony, \& Glover, Derek. (2014). School leadership models: What do we know? School Leadership \& Management, 34(5), 553-571. 
DiPaola, Michael, Tschannen-Moran, Megan, \& Walther-Thomas, Chriss. (2004). School principals and special education: Creating the context for academic success. Focus on Exceptional Children, 37(1), 1-10.

Fullan, Michael. (2014). The principal: Three keys to maximizing impact. John Wiley \& Sons.

Harries, Madiistriyatno. (2020). UKM Dan Kapabilitas Inovasi: Tantangan Di Era Industri 4.0.

Hénard, Fabrice, \& Roseveare, Deborah. (2012). Fostering quality teaching in higher education: Policies and practices. An IMHE Guide for Higher Education Institutions, 7-11.

Madiistriyatno, Harries, \& Sofianto, Sofianto. (2021). Effect of Supervision and Discipline on Improving Employee Work Effectiveness at Kebayoran Baru Tax Service Office. Eduvest-Journal Of Universal Studies, 1(6), 521-526.

Oyewole, Babatope Kolade, \& Alonge, Hezekiah Ogbomida. (2013). Principals' instructional supervisory role performance and teachers' motivation in Ekiti Central Senatorial District of Ekiti State, Nigeria. Journal of Educational and Social Research, 3(2), 295.

Schleicher, Andreas. (2012). Preparing teachers and developing school leaders for the 21st century: Lessons from around the world. ERIC.

Stronge, James H., \& Xu, Xianxuan. (2021). Qualities of effective principals. ASCD.

Wanzare, Zachariah. (2012). Instructional supervision in public secondary schools in Kenya. Educational Management Administration \& Leadership, 40(2), 188-216.

Zakuan, Norhayati, Muniandy, Shalini, Saman, Muhamad Zameri Mat, Ariff, Mohd Shoki Md, Sulaiman, Sapiah, \& Abd Jalil, Rozita. (2012). Critical success factors of total quality management implementation in higher education institution: a review. International Journal of Academic Research in Business and Social Sciences, 2(12), 19. 